\title{
Toward a tourism destination brand equity of coastal tourism of Pangandaran Regency
}

\author{
Ibrahim Rashid \\ School of Business and Management, Institut Teknologi Bandung, Indonesia \\ Correspondence author email: ibrahim_rashid@sbm-itb.ac.id
}

\begin{abstract}
Indonesia is one of the countries where tourism is the major contributors to the GDP. There are province and districts in Indonesia that mainly focused on the tourism business, Pangandaran is one of them. As a new district, Pangandaran is still trying to develop its brand as a tourist destination. This study aims to provide perceptual maps of Pangandaran as a brand compared to other coastal tourism destination. The study used Multidimensional Scaling (MDS), to inquire about the brand image of various coastal destination in Indonesia among domestic tourist. Two dimensions consisted of performance and value are used to measure the destination brand. More profound questions are also asked to inquire about factors that may influence tourist visitation. The result indicates that the Pangandaran brand as a tourism destination is perceived as a domestic oriented destination. A suggestion based on five steps of brand building is proposed to improve Pangandaran.
\end{abstract}

Keywords: Competitiveness, Destination branding, Multidimensional Scaling (MDS), Pangandaran, Tourism

JEL Classifications: O21, Q26, R11

\section{INTRODUCTION}

Tourism is one of the most important economic activities in the modern day. In the past decade, tourism contributed to $10 \%$ of global GDP. Furthermore, tourismrelated jobs account for 1 in 10 of the population. Globally, tourism accounts for $30 \%$ of services exports and have created many job opportunities for the population. It can be said that tourism is a significant force of the global economy, especially in developing countries. Indonesia is one of the countries where tourism is a significant contributor to the economy. Indonesia is globally recognized for relatively cheap natural resources and emphasizing culture in tourism. Tourism consists of $6 \%$ of the country total exports, and in response, the government invested $9 \%$ of its budget in tourism (World Economic Forum, 2017).

In developing countries such as Indonesia, tourism plays an important role in economic growth. The existence of tourism in a particular area can open up more opportunities. These opportunities can be in the form of an immediate and direct effect such as more employment and enterprise opportunities, to a broad more dynamic effect on the economy and social (Ashley, De Brine, Lehr, \& Wilde, 2007 ). In the past, researches had documented the impact of tourism on economic growth. One research in 
Mauritius, a small island country in the Indian Ocean, documented the impact of tourism arrival on the economic growth of the nation (Durbarry, 2002). Other research in Greece, a well-known international tourist destination, indicated that there is a causal relationship between international tourism earning, real exchange rate, and economic growth of the nation (Dritsakis, 2004). Citing the impact of tourism in other nations and its already observable effect in the economy, the Indonesian government included tourism growth as one of the strategies in developing the national economy (LPEMFEBUI, 2018).

Indonesia is the largest archipelago in the world, consisted of around 17000 islands each with its cultural and natural diversity. As such, the diversity of Indonesia natural and cultural heritage gave birth to the various tourism destination, some are famous as an international tourism destination, and some are more famous among domestic tourist. Pangandaran is one of the tourist destinations in Indonesia that are popular among domestic tourists.

Pangandaran is a regency in West Java, Indonesia, that split from the neighboring Ciamis Regency in 2012. Before the split, Pangandaran itself is already a well-known tourism destination among domestic tourist. After the split, the newly formed Pangandaran government are attempting to further Pangandaran potential as a tourism destination. Pangandaran aims to be a world-class tourism destination like Bali and Gili Trawangan, two examples of tourism destination in Indonesia that are successfully developed to become an international tourist destination. (Dinas Pariwisata dan Kebudayaan Kabupaten Pangandaran, 2017). Unfortunately, as of now, Pangandaran as a tourism destination is underdeveloped in many aspects; from infrastructure, cultural uniqueness, local products, and management. In short, there is a lot of problems that the Pangandaran government need to overcome in order to become a world-class tourism destination. Therefore to overcome these problems Pangandaran local government attempt to improve the Pangandaran brand image.

To improve the brand image of Pangandaran, Pangandaran government need to understand the strength and weaknesses of Pangandaran from the eye of its visitors. Destination branding is a concept that can be used to understand the visitor's perception. Destination branding refers to activities that aim to emphasize the underlying image and associative knowledge that people have on a destination. These activities can include the creation of graphics (name, symbol, or logo) related to the destination or developing the essential cultural and natural resources (Evangelista \& Dioko, 2011). Unlike the branding of a product, the process of branding a destination requires the marketer to understand the inherent characteristic of a product including their related brand equity (Lim \& Weaver, 2014). Brand equity itself is a concept that refers to the attached value of a brand name. Unlike a real product, the brand equity of a destination itself differs in its multidimensionality. Therefore, the measurement of brand equity itself is less straightforward and prone to mistake (Gartner, 2014). In this study, the scale developed by (Lassar, Mittal, \& Sharma, 1995) and used by (Evangelista \& Dioko, 2011) in order to measure brand equity.

In this study, Pangandaran as a brand is compared with its competitor at the national level. This comparison made in order to understand the position of Pangandaran better. The comparison is made using Multi-Dimensional Scaling (MDS). This method is used to visualize the differences between tourism destination in 
Indonesia. The comparison made by using scale developed for the social aspect of brand equity. Since the main visitors of Pangandaran are domestic tourists, this study also aims to understand the factors that influence domestic tourists decision in choosing a tourism destination. This study also aims to formulate suggestion based on the result of the perceptual map on how to develop Pangandaran as a tourism destination.

\section{METHODS}

Several works of literature discuss brand equity of tourism destination, destination branding, and destination image. The paper by (Campelo, Aitken, Thyne, \& Gnoth, 2013), discuss building a sense of place model in order to determine the factor that determines and influence the sense of place of a destination. Gartner discusses the concept of brand equity of a tourism destination in general (Gartner, 2014). The attempt to compare tourism destinations using Multidimensional Scaling (MDS) have been made by (Claveria \& Polluzi, 2016). Gartner also used MDS in order to categorize tourism activities (Gartner, 1989). Pike in his paper, aims to measure brand equity over time and provide a good insight into the concept of brand equity in the context of a tourism destination (Pike, 2009). Compared to the above literature this paper aims not only aim to measure brand equity or compare the attributes of destinations but to combine those methods and present the result through MDS.

This study aims to create a perceptual map of Pangandaran based on five dimensions of destination brand equity (performance, value, attachment, trust, and image). The perceptual map is created through an interdependence multivariate analysis method called Multi-Dimensional Scaling (MDS). MDS is a method that aims to find structure in a set of distance measures between cases or objects. Additionally, this study measures the criteria for domestic tourist when choosing a tourism destination.

Aside from Multidimensional Scaling (MDS), this study utilized other methods to support the finding. Several semi-structured interviews were conducted to explore the context of Pangandaran tourism. The findings of these interviews will be used to support the findings of MDS. Furthermore, the interview findings will help describe the context of this study.

An exploratory interview is conducted in order to support the finding of the research. The respondents consisted of SME owners and local government officers. The interview method used is a semi-structured interview with the aim to gain a better understanding of the actual context of Pangandaran. The result of the interview is used to support the quantitative finding and help to formulate suggestion for the government. The list of respondent and important points they brought can be found in the Table 1 .

The data set for MDS is collected through an online questionnaire, with the target population of Indonesia. The sampling method used is probability sampling, a sampling method that assumes that every individual in a given population can be sampled.

This study focus on the brand equity dimension of performance and value. The choice to focus on these two dimensions was made because the researcher deemed that these two dimensions can best represent domestic tourist judgment through the data collection method employed. Furthermore, the information regarding these two dimensions is easily obtainable, therefore the comparison between the research and real context can be done. The easiness to obtain information about the two dimensions might help eliminate bias since not all respondents have visited the destinations. 
Table 1. Interview findings

\begin{tabular}{|c|c|c|}
\hline Informants & Important Notes & Findings \\
\hline M1 & $\begin{array}{l}\text { Co-founder of Pangandaran Tour \& } \\
\text { Travel, a travel agent company }\end{array}$ & $\begin{array}{l}\text { - Role of travel agents } \\
\text { - Importance of travel association }\end{array}$ \\
\hline $\mathrm{S}$ & $\begin{array}{l}\text { An entrepreneur who own two } \\
\text { shops of fish products and a } \\
\text { seafood restaurant }\end{array}$ & $\begin{array}{l}\text { - Lack of supply material } \\
\text { - Lack of equipment and financial } \\
\text { support }\end{array}$ \\
\hline $\mathrm{T}$ & $\begin{array}{l}\text { An entrepreneur who own two } \\
\text { clothing shops and souvenir shops }\end{array}$ & $\begin{array}{l}\text { - Lack of sustainability from tourism } \\
\text { - The negative impact of shopping } \\
\text { center relocation }\end{array}$ \\
\hline SN & $\begin{array}{l}\text { An entrepreneur who owns a } \\
\text { seaside steakhouse and a hotel }\end{array}$ & $\begin{array}{l}\text { - Current regulation as a hindrance for } \\
\text { growth } \\
\text { - The bad infrastructure of new } \\
\text { shopping and restaurant district }\end{array}$ \\
\hline M2 & $\begin{array}{l}\text { An entrepreneur who owns a } \\
\text { seafood restaurant }\end{array}$ & $\begin{array}{l}\text { - The information gap between } \\
\text { government and businesses }\end{array}$ \\
\hline $\mathrm{D}$ & $\begin{array}{l}\text { Head of Destination Management } \\
\text { Department of Pangandaran Branch } \\
\text { of Tourism \& Culture ministry }\end{array}$ & $\begin{array}{l}\text { - The low capability of existing } \\
\text { human resource } \\
\text { - Problem is marketing }\end{array}$ \\
\hline $\mathrm{Mn}$ & $\begin{array}{l}\text { A staff of Pangandaran Regency } \\
\text { government }\end{array}$ & $\begin{array}{l}\text { - Coconut is the main product of } \\
\text { Pangandaran } \\
\text { - Profile of Pangandaran } \\
\text { - Private land ownership of potential } \\
\text { tourism site causing troubles } \\
\text { - Pangandaran still developing its } \\
\text { concept }\end{array}$ \\
\hline $\mathrm{Mg}$ & $\begin{array}{l}\text { Creative Economy Department of } \\
\text { Pangandaran Branch of Tourism \& } \\
\text { Culture ministry }\end{array}$ & $\begin{array}{l}\text { - Lack of brand image } \\
\text { - An only small part of the population } \\
\text { engaged in tourism } \\
\text { - The Ministry tried to guide several } \\
\text { entrepreneurs to develop the unique } \\
\text { product of Pangandaran }\end{array}$ \\
\hline As & $\begin{array}{l}\text { Physical and Infrastructure } \\
\text { Department of Pangandaran } \\
\text { Regency government }\end{array}$ & $\begin{array}{l}\text { Lack of uniqueness compared to } \\
\text { other destinations } \\
\text { - Cooperation with a university in } \\
\text { order to develop architectural } \\
\text { uniqueness }\end{array}$ \\
\hline $\mathrm{R}$ & $\begin{array}{l}\text { Cooperative Department of } \\
\text { Pangandaran Regency government }\end{array}$ & $\begin{array}{l}\text { - Coconut is still the main income of } \\
\text { Pangandaran } \\
\text { - Tourism is around tenth in its } \\
\text { contribution to regional income } \\
\text { - Lack of capital support to help } \\
\text { businesses grow }\end{array}$ \\
\hline A & $\begin{array}{l}\text { Planning Department of } \\
\text { Pangandaran Regency government }\end{array}$ & $\begin{array}{l}\text { - No real engagement between SME } \\
\text { and tourism in Pangandaran } \\
\text { - Not enough demand for SME } \\
\text { products in tourism } \\
\text { - In some area, the locals have the } \\
\text { initiative to turn their locale into a } \\
\text { tourism destination }\end{array}$ \\
\hline
\end{tabular}


For the first set of data, the respondents will be asked to rate seven coastal tourism destination in Indonesia based on the two dimensions of tourism destination brand equity. Each respondent will be asked to rate each of the two dimensions of these tourism destinations. These destinations were chosen based on information from travel sites. The destinations are:

1. Pangandaran (West Java)

2. Pelabuhan Ratu (West Java)

3. Kuta (Bali)

4. Nusa Dua (Bali)

5. Gili Trawangan (Nusa Tenggara Barat)

6. Karimun Java (Central Java)

7. Seribu Islands (DKI Jakarta)

For the second set of information, the respondent will be asked to rank ten criteria of a tourism destination based on importance. The criteria and their codes are:

1. Goods and services price (F1): Affordable and reasonable prices of goods and services of the destination

2. Cultural uniqueness (F2): Unique culture that can be the attraction for tourists

3. Essential infrastructure availability (F3): The existence of necessary infrastructure such as toilet, phone signal, roads, etc.)

4. Accessibility (F4): The abundance of transport methods to reach the destination

5. Hygiene (F5): The ability of the provider to keep the destination clean

6. Experience (F6): Activities that are unique or memorable

7. Information availability (F7): The easiness of finding information related to the destination

8. Natural uniqueness(F8): Natural environment or landmark that can attract tourists

7. Service quality (F9): How well a service can deliver customer expectation

9. Community acceptance(F10): Willingness of locals to accept the presence of tourists

These variables are based on a paper by (Assaker, Vincenzo, \& O'Connor, 2011) and earlier exploratory interview with tourism providers and stakeholders. The variables encompass the four significant tourism components: economy, social, natural, and infrastructure. The incorporation of these components of tourism is done in the hope that the question is given in the survey cover the factors that can be deemed to be necessary by the respondents.

The data processing method utilized $\mathrm{R}$ programming as a tool for statistical analysis. The data are collected first converted into excel files which then used as an input in R programming tool. The study then used the MDS programming code to process the data. The result of the processing is a perceptual map of the destinations and factors, which in this case is processed with a two-dimensional aspect. As of now, the number of data collected is 39 data.

\section{RESULTS AND DISCUSSION}

\section{Interview result}

The analysis of 11 interviews reveals the problem in Pangandaran tourism. The respondents consist of government officials and entrepreneurs, important stakeholders that enable tourism in Pangandaran. The interviews aim to explore the business environment of Pangandaran tourism, therefore the analysis will be focused on that particular area. Despite the purpose of the interview, the analysis can be used to describe the overall context of Pangandaran tourism. 


\section{Interview with small medium enterprise (SME) owners}

Five SME owners were interviewed, in the preliminary interview. The SME owners consist of two restaurant and hotel owners, one restaurant and fish products processor, one souvenir and clothes shop owners, and one travel agent owners. All of the SME feel that government support is lacking. M-2, a restaurant and hotel owner, for example, stated that:

“ The government, don't want to know whether entrepreneurs make profit or deficit. Now taxes. One million, five hundred thousand, fifty thousand. Many guests complain! Maybe in cities, it's that way. But here is different!"

From that statement, the government new tax policy is one of the main sources of complaint among SME owners. Another statement from M-2, also indicates that there is some frustration among SME owners in their relationship with the government. M-2 said that:

"Meeting is meeting, but it's useless. But it's always tax, even if we submit our suggestion it's always be ignored!"

Another entrepreneur S, a restaurant owner and fish product processor, also support this statement. S stated that:

"Every time we complain, nobody answer"

Relocation policy is another government policy that SME owners complain about. The relocation policy is deemed harmful for Pangandaran. Because of this policy, SME owners have to give up their strategic business location which impacts their income. $\mathrm{T}$, a souvenir shop owner stated that:

"..because now we are still relocating, destinations do not want to go there. Usually, on the beachside is easy, people can shop everywhere on the beach. Now many tourists take their money back home."

Overall, the SME owners are dissatisfied with the government mainly from the taxes and relocation policy. Despite those problems, the income of SME and large business owners is stable. It is because, during peak visitation times, businesses in Pangandaran can double or even triple their price. Therefore, businesses in Pangandaran can still have steady incomes.

\section{Interview with government officers}

Six government officers are interviewed in the preliminary research. These six government officials provide the general context of Pangandaran tourism. Pangandaran is still growing as a tourism destination. Government officials state that they are still trying to develop the uniqueness of Pangandaran. Pangandaran government is still developing unique products and existing traditional culture in order to attract visitors. In terms of uniqueness in Pangandaran, As, stated that:

“...In here, we still need to develop uniqueness. In my opinion, right now it's mostly regional characteristic, still not developed into brand..."

The interview also indicates that although uniqueness development is one of the concerns of Pangandaran government right now, infrastructure development is Pangandaran government primary concern right now. Pangandaran government is trying to build necessary infrastructures and impose rules related to maintenance and area zoning such as restriction of fishermen boats and restriction of street peddlers. The relocation policy of Pangandaran is related to the infrastructure development program. Furthermore, the interview also indicates that the stakeholders of Pangandaran only concerned about their own interests. From land disputes to locals that aren't engaged in tourism, Pangandaran government is facing a heavy task to bring these stakeholders 
together. The statement regarding the solution of this phenomenon by KP is the following:

“You can't rely only on Mr. M from Creative Economy Division, and then from

industry, and from agriculture, everything must be comprehensive, you can't do it partially. It means there is a correlation between potential, lifestyle, and behavior of the stakeholders."

\section{MDS result}

\section{Perceptual mapping of performance dimension}

Figure 1, shows the Multidimensional Scaling (MDS) result of the performance dimension between the selected destinations. The performance dimension itself refers to how customer judges the fault-free attributes of a destination (Evangelista \& Dioko, 2011). The final stress value of all the iteration is 0.131 , an indication of fair value for the goodness of fit. From the perceptual map, Pangandaran is tightly clustered with Pelabuhan Ratu, a coastal tourist destination located in the South of West Java, just like Pangandaran. Since the performance dimension is a measure of activity available and natural resources of the destination, it is not surprising that beaches that share similar characteristics are clustered together.

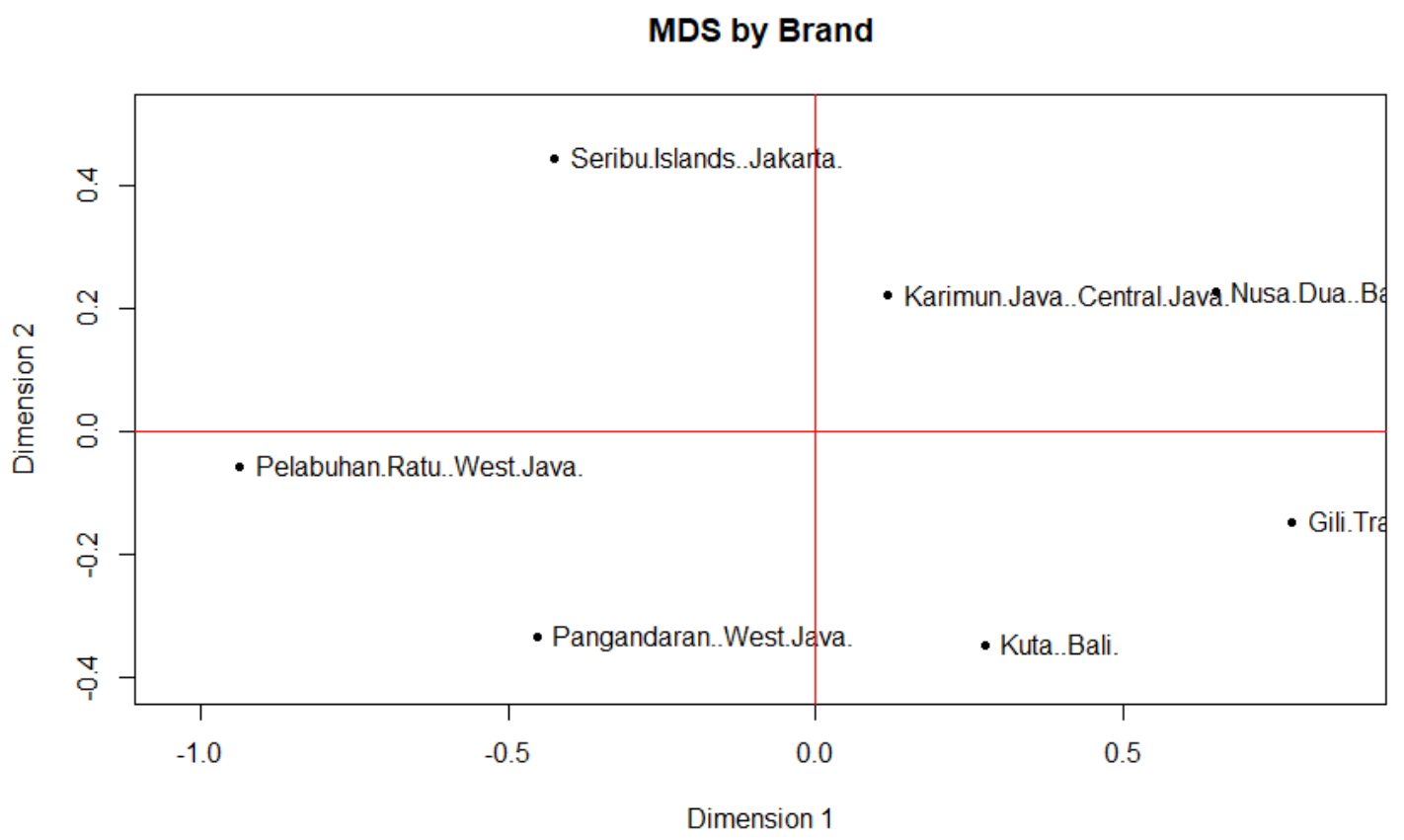

Figure 1. Performance dimension perceptual mapping

From the result, Kuta and Gili Trawangan are clustered together. Both of these destinations shared a similar characteristic. Both Kuta and Gili Trawangan is a destination that experiences a development boom, which gave birth to various accommodation and entertainment places of the same kind. Another group from the result, Karimun Java and Nusa Dua share another unique characteristic. Both of these destinations offer luxurious resorts in combination with natural beauty. Both also offer water-related activity such as diving in Karimun Java and watersport in Nusa Dua. Seribu Islands has grouped alone from the result. The vastly different characteristic of Seribu Islands as a National Park contributes to this result. As a National Park, Seribu 
Islands main concern is not on attracting visitors but also protecting its natural resources, this policy can result in its unique clustering. Lastly, Pangandaran is grouped with Pelabuhan Ratu, both located in West Java. Both destinations in the group share a similar characteristic, from their beaches to their cultures. Both of these destinations is a popular local tourist destination because of their affordability and accessibility.

\section{Perceptual mapping of value dimension}

Figure 2, shows the Multidimensional Scaling (MDS) result of the value dimension between the selected destinations. The value dimension refers to utility gained from visiting a destination compared to the cost of the experience (Evangelista \& Dioko, 2011). The final stress value of all the iteration is 0.171 , an indication of the excellent fit of the model. The result shows that Pangandaran is clustered with Pelabuhan Ratu because of their similar characteristics.

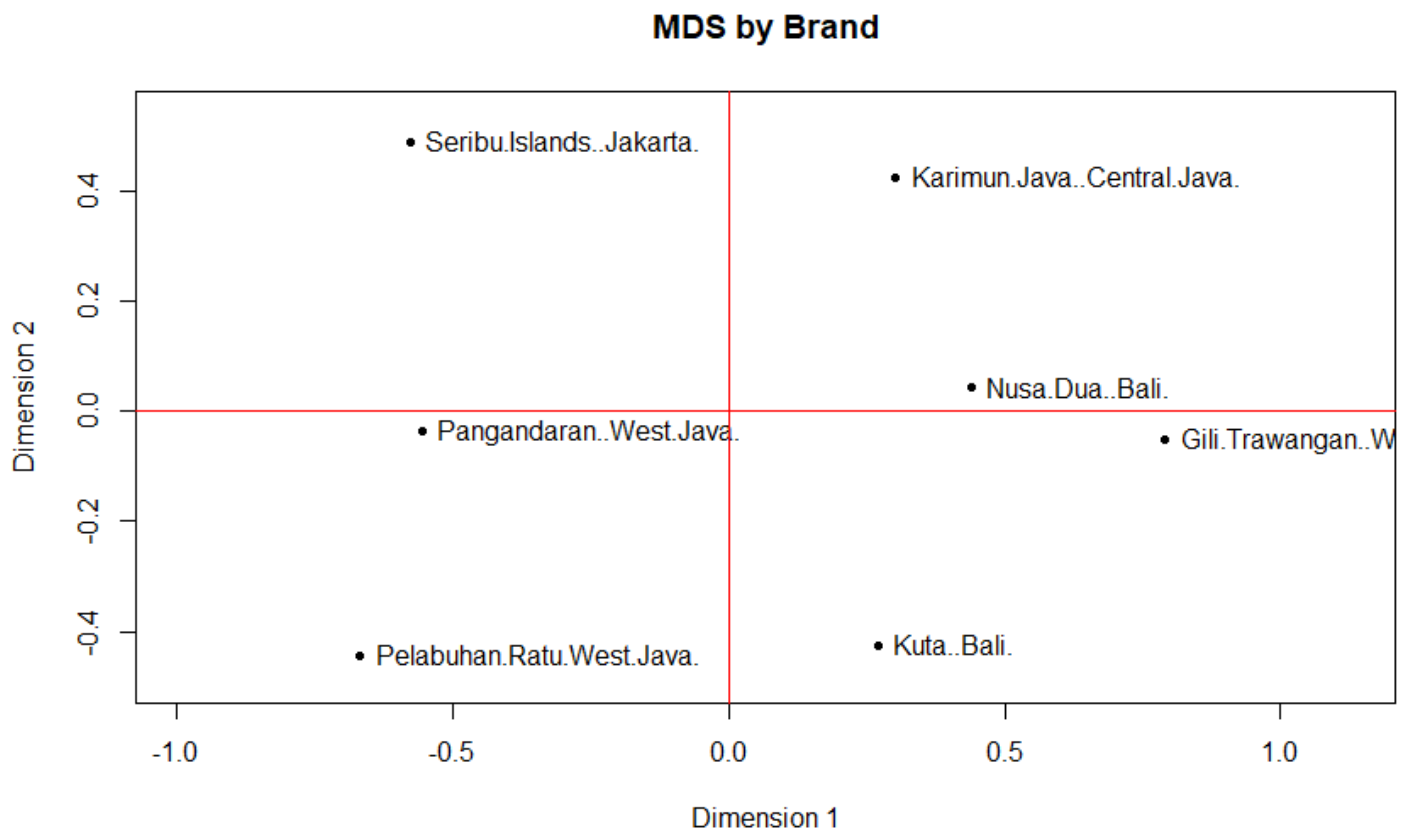

Figure 2. Value dimension perceptual mapping

The result shows that the clustering of the destinations is not much different from the performance dimension. This result could be attributed to the relation the value dimension have with the performance dimension. Nusa Dua and Karimun Java, for example, are different in terms of accessibility. Nusa Dua, located in Bali, is more accessible because of the existence of international airport and various mode of transportation. Meanwhile, to get into Karimun Java visitors have to fly from Surabaya to Dewandaru Airport to a neighboring island, in which visitors can use a boat or ferry to Karimun Java. Despite their different level of accessibility, both destinations are clustered together because of the similar experience they offer. This phenomenon can be observed in other clusters, indicating that domestic tourists value experience more than distance and cost.

\section{Perceptual mapping of factor affecting domestic tourist visitation}

Figure 3, shows the Multidimensional Scaling (MDS) result of visitation factors. These results indicate the factors that influence domestic tourists reason for visitation 
Dimension 1 of the figure refers to objectivity. Meanwhile, dimension 2 refers to importance.

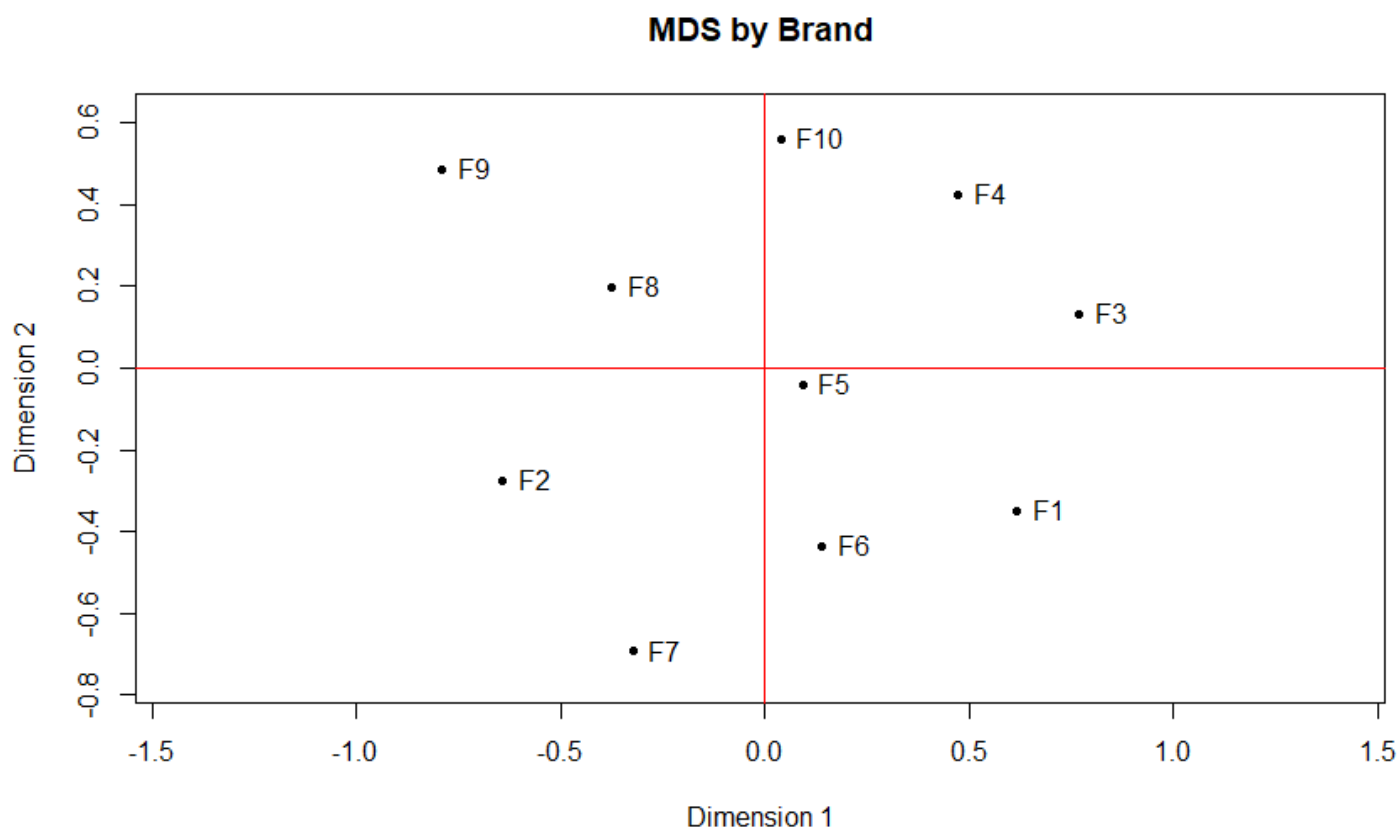

Figure 3. Tourists visitation factors perceptual mapping

The final stress value of all the iteration is 0.25 , an indication of the excellent fit of the model. Dimension 2 of the result indicate importance and dimension 1 indicate subjectivity of the factor. Based on the result of necessary infrastructure (F3), accessibility (F4), and community acceptance (F10) are three things that are deemed as a principal, low subjectivity factor. On the contrary, Information availability (F7) and cultural uniqueness (F2) less critical, highly subjective factors. Natural uniqueness (F8) and service quality (F9) can be categorized as less subjective, but less critical factors. Meanwhile, goods and service price (F1), hygiene (F5), and experience (F6) can be categorized as critical subjective factors.

\section{Discussion}

The result of performance and value dimension perceptual mapping indicate that Pangandaran is perceived differently from other established tourism destination. Pangandaran is not as developed in terms of the sheer amount of business and entertainment as Kuta and Gili Trawangan. Pangandaran also does not have a natural beauty and luxurious resorts like Nusa Dua or Karimun Java. From the performance dimension mapping, Pangandaran is a destination that is more domestic tourist oriented than other destinations. From this result, Pangandaran can position itself as a go-to destination for domestic tourists.

The value dimension mapping result shows that Pangandaran is clustered with Pelabuhan Ratu, another tourist destination that is located in West Java, Indonesia. Since both of these locations are located in West Java both of these locations can be easily accessible by car for a lot of domestic tourists. Accessibility coupled with affordability could be the strength of Pangandaran in searching for their uniqueness. Pangandaran government could brand Pangandaran as an affordable and accessible destination in order to attract more domestic visitors. 
Based on the result of the perceptual map the factor that is deemed most important by domestic tourists is necessary infrastructure. Domestic tourists in Indonesia does not deem natural and cultural uniqueness as an essential factor of visitation, although experience is deemed as one of the more essential factors. Other vital factors from the perspective of domestic tourists are price, accessibility, hygiene, and community acceptance. Based on this result the local government of Pangandaran is on the right track of prioritizing the development of necessary infrastructures, although still lacking in other important factors. In Pangandaran, there are no regulations regarding prices, which contribute to inflated prices on peak visitation time. Pangandaran government could enforce a strict policy regarding pricing if Pangandaran wants to brand itself as an affordable tourist destination.

To improve the brand equity of Pangandaran, several suggestions are made. According to the five steps of building a destination brand, the first step is vision and stakeholder management (Balakrishnan, 2009). Pangandaran needs to unite the visions of its stakeholders. As of now, Pangandaran stakeholders are each have their vision of tourism in Pangandaran. The government of Pangandaran currently interested only on tax revenue, meanwhile the SME owners of Pangandaran are concerned about their income because of the tax policy. Pangandaran government needs to find a driver that can unite the vision of Pangandaran stakeholders. In the context of Pangandaran, this vision can be economic goals. Based on the interview, the stakeholders of Pangandaran is economically driven in their motivation to participate in tourism. Therefore, an economic goal other than regional income to raise the engagement of the stakeholders. This economic goal could be to build an economic benefit from tourism so that every resident of Pangandaran can benefit from it.

The second step of building a brand is the target customer and portfolio matching (Balakrishnan, 2009). Pangandaran needs to match their branding strategy to the portfolio of its visitors. As of now the main visitors of Pangandaran is domestic, which usually come in a large group using buses or as a family using a car. The length of their stay is usually not long; visitors mostly stay only one night at the weekend. Since the primary demographic of Pangandaran are domestic tourists, the government could employ integrative diversification strategy in order to appeal to their market These strategies could include integrating the usage of Pangandaran local products in tourism activity in order to enhance Pangandaran image as a coastal tourism destination or integrating various activity in beaches of Pangandaran in order to strengthen their image (Benur \& Bramwell, 2015).

The third step in building a brand is brand positioning and differentiation. Pangandaran could differ its brand from other coastal destinations through its product and culture. The southern coast of West Java is famous for the Javanese and Sundanese legend of Queen of the Indian Ocean. Pangandaran can uphold this story in other to attract domestic visitors. Pagandaran can also strengthen their image of an affordable and accessible tourism destination. By upholding this image Pangandaran can find its unique segment and develop its strategy according to that.

The fourth step in building a brand is a communication strategy (Balakrishnan, 2009). This step is related to how a destination delivers its product across the media. Since word of mouth and electronic word of mouth is more influential in determining visitation, Pangandaran local government should put effort into building an excellent online platform and methods to promote Pangandaran(Evangelista \& Dioko, 2011). The last step in building a brand is through managing responses (Balakrishnan, 2009). Pangandaran developers must monitor the online sentiments of their products in order to 
be competitive.

Last, this study shows that Multidimensional Scaling (MDS) can be used to measure the brand equity of a destination. This study used to explore the data on the performance and value dimension of Indonesian tourist destinations. This method reveals the relationship between objects through their distance in the spatial map (Saeed, Nam, Haq, \& Muhammad Saqib, 2018). The result of this study indicates that Pangandaran is perceived differently from other more established tourist destinations. This study shows that the result of this spatial map can be used to create a suggestion for Pangandaran further development.

\section{CONCLUSIONS AND RECOMMENDATIONS}

\section{Conclusions}

The MDS result indicates that the performance and value of Pangandaran are different compared to other tourist destinations. Pangandaran tourism is seen as more affordable and accessible in the eye of domestic tourists, albeit less luxurious and less beautiful in terms of natural resources. This perception of Pangandaran can be a strong point in the development of Pangandaran.

There are several limitations to this study. First, there is a probability not all respondents have visited about the destinations presented in the question. Therefore, the respondents have to rely on their limited knowledge to answer the questionnaire. Second, the interview result is limited because of time constraints. Therefore, the problem existed in this study may not be presented in-depth. Third, the research only encompasses several coastal tourism destinations in Indonesia. Expanding the scope into more coastal destinations or other types of tourism destinations could be done to provide a more comprehensive view.

\section{Recommendations}

Further research could elaborate more on the finding of the performance and value dimension of Pangandaran. Since MDS only provide the differences through the spatial map, a better understanding of the context of each tourism destination could provide a more comprehensive explanation of the differences between Pangandaran and other tourist destinations. Furthermore, since this study only explores some aspects of brand equity, further study could explore other dimensions of brand equity to provide a more complete picture of visitor's perception. The study suggests several courses of action in order to develop Pangandaran. These suggestions are built on the basis of the spatial map provided by MDS. This result shows that MDS is a suitable technique to explore the comparison between tourism brands.

There is some policies recommendation that can be implemented in Pangandaran. Pangandaran is the most affordable and accessible among popular coastal tourism destination. Therefore, the provider of tourism should focus on strengthening this aspect of Pangandaran. First, the Pangandaran tourism providers should provide support for the SMEs in Pangandaran. These supports could be in the form of facilities to create their product, markets that specialized in selling local products, or even financial and other capital supports. By supporting the SMEs, the provider can create an environment that is filled with affordable products. Second, the provider must educate the SMEs and residents that interested in opening their business on production, marketing, and other business processes. The purpose is to maintain or improve the quality of SME products. By combining affordability with acceptable quality, Pangandaran can improve its position among other coastal destinations. 


\section{REFERENCES}

Ashley, C., De Brine, P., Lehr, A., \& Wilde, H. (2007 ). The Role of Tourism Sector in Expanding Economic Opportunity. Cambridge: Kennedy School of Government, Harvard University.

Assaker, G., Vincenzo, E. V., \& O'Connor, P. (2011). Modelling a causality network for tourism development: An empirical analysis. Journal of Modelling in Management, 6(3), 258-278.

Balakrishnan, M. S. (2009). Strategic branding of destinations: a framework. European Journal of Marketing, 43(5), 611-629.

Benur, A. M., \& Bramwell, B. (2015). Tourism product development and product diversification in destinations. Tourism Management, 50, 213-224.

Campelo, A., Aitken, R., Thyne, M., \& Gnoth, J. (2013). Sense of Place: The Importance for Destination Branding. Journal of Travel Research, 53(2), 154-166.

Claveria, O., \& Polluzi, A. (2016). Positioning and clustering of the world's top tourist destinations by means of dimensionality reduction techniques for categorical data. Journal of Destination Marketing and Management, 6(1), 22-32

Dinas Pariwisata dan Kebudayaan Kabupaten Pangandaran. (2017). Data Kunjungan Wisata. Retrieved October 20, 2017, from Dinas Pariwisata dan Kebudayaan Kabupaten Pangandaran. Available at: http://dispar.pangandarankab.go.id

Dritsakis, N. (2004). Tourism as a Long-Run Economic Growth Factor: An Empirical Investigation for Greece Using Causality Analysis. Tourism Economics, 10(3), 305-316.

Durbarry, R. (2002). The Economic Contribution of Tourism in Mauritius. Annals of Tourism Research, 29(3), 862-865.

Evangelista, F., \& Dioko, L. A. (2011). Interpersonal influence and destination brand equity perceptions. International Journal of Culture, Tourism and Hospitality Research, 5(3), 316-328.

Gartner, W. C. (1989). Tourism Image: Attribute Measurement of State Tourism Product Using Multidimensional Scaling Techniques. Journal of Tourism Research, 28(2), 16-20.

Gartner, W. C. (2014). Brand equity in a tourism destination. Place Branding and Public Diplomacy, 10(2), 108-116.

Lassar, W., Mittal, B., \& Sharma, A. (1995). Measuring customer- based brand equity. Journal of Consumer Marketing, 12(4), 11-19.

LPEM-FEBUI . (2018). Kajian Dampak Sektor Pariwisata Terhadap Perkenomian Indonesia. Jakarta: LPEM-FEBUI .

Lim, Y., \& Weaver, P. A. (2014). Customer-based Brand Equity for a Destination: the Effect of Destination Image on Preference for Products Associated with a Destination Brand. International Journal of Tourism Research, 16(3), 223-231.

Pike, S. (2005). Tourism destination branding complexity. Journal of Product \& Brand Management, 14(4), 258-259.

Pike, S. (2009). Destination Branding Case Study: Tracking Brand Equity for an Emerging Destination Between 2003 and 2007. Journal of Hospitality \& Tourism Research, 34(1), 124-139.

Saeed, N., Nam, H., Haq, M. I. U., \& Muhammad Saqib, D. B. (2018). A Survey on Multidimensional Scaling. ACM Computing Surveys, 51(3), 1-25.

World Economic Forum. (2017). The Travel \& Tourism Competitiveness Report. Geneva: World Economic Forum. 